\title{
Rescue Thrombectomy in Large Vessel Occlusion Strokes Leads to Better Outcomes than Intravenous Thrombolysis Alone: A 'Real World' Applicability of the Recent Trials
}

\author{
Raul G. Nogueira ${ }^{a}$ Osama O. Zaidat ${ }^{\mathrm{b}}$ Alicia C. Castonguay ${ }^{\mathrm{b}}$ Diogo C. Haussen ${ }^{\mathrm{a}}$ \\ Coleman O. Martin ${ }^{c}$ William E. Holloway ${ }^{c}$ Nils Mueller-Kronast ${ }^{d}$ Joey English ${ }^{e}$ \\ Italo Linfante $^{f}$ Guilherme Dabus $^{f}$ Tim W. Malisch $^{g}$ Franklin A. Mardeng \\ Hormozd Bozorgchami ${ }^{h}$ Andrew Xavier ${ }^{i} \quad$ Ansaar T. Rai ${ }^{j}$ Michael T. Froehler $^{k}$ \\ Aamir Badruddin' Thanh N. Nguyen ${ }^{m} \quad$ M. Asif Taqi ${ }^{n} \quad$ Michael G. Abraham ${ }^{\circ}$ \\ Vallabh Janardhan $^{p} \quad$ Albert J. Yoo ${ }^{p} \quad$ Hashem Shaltoni $^{q} \quad$ Alex Abou-Chebl $^{r}$ \\ Peng R. Chens ${ }^{\mathrm{s}}$ Gavin W. Britz ${ }^{\mathrm{t}}$ Roberta Novakovic ${ }^{\mathrm{u}}$ Ashish Nandav \\ Ritesh Kaushal $^{w}$ Mohammad A. Issa $^{b}$ Michael R. Frankel ${ }^{a}$ Rishi Gupta ${ }^{x}$ \\ ${ }^{a}$ Department of Neurology, Emory University School of Medicine, Atlanta, Ga., ${ }^{b}$ Department of \\ Neurology, Medical College of Wisconsin, Milwaukee, Wis., ${ }^{c}$ St. Luke's Neuroscience Institute,

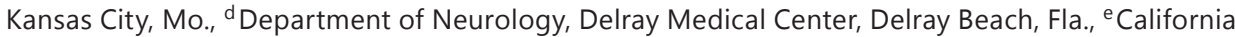 \\ Pacific Medical Center, San Francisco, Calif., f Division of Interventional Neuroradiology, Baptist \\ Cardiac and Vascular Institute, Miami, Fla., gAlexian Brothers Medical Center, Elk Grove Village, Ill., \\ h Oregon Health and Sciences, Portland, Oreg., 'Department of Neurology, Wayne State University \\ School of Medicine, Detroit, Mich., jDepartment of Radiology, West Virginia University Hospital, \\ Morgantown, W.Va., ${ }^{k}$ Department of Neurology, Neurosurgery, and Radiology, Vanderbilt University \\ Medical Center, Nashville, Tenn., 'Department of Neurosurgery, Presence Saint Joseph Medical Center, \\ Joliet, Ill., m Department of Neurology, Boston University School of Medicine, Boston, Mass., nesert \\ Regional Medical Center, Palm Springs, Calif., 'University of Kansas Medical Center, Kansas City, Kans.,

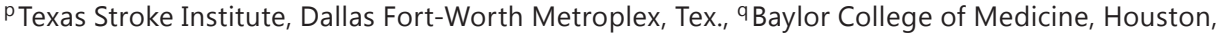 \\ Tex., ' Department of Neurology, University of Louisville Medical School, Louisville, Ky., ${ }^{\text {s Department }}$ \\ of Neurosurgery, University of Texas, Houston, Tex., ${ }^{\mathrm{t}}$ Department of Neurosurgery, Methodist \\ Neurological Institute, Houston, Tex., "Departments of Radiology and Neurology, UT Southwestern

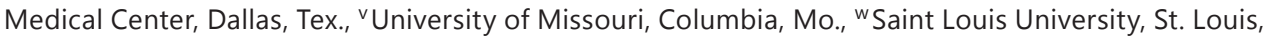 \\ Mo., and ${ }^{x}$ Department of Neurosurgery, Wellstar Medical Group, Marietta, Ga., USA
}

\section{Key Words}

Rescue thrombectomy · Large vessel occlusion · Intravenous thrombolysis · Interventional Management of Stroke III trial
Abstract

Background: The Interventional Management of Stroke III (IMS-III) trial demonstrated no benefit for intravenous recombinant tissue plasminogen activator (IV rt-PA) followed by endovascular therapy versus IV rt-PA alone. However, IMS-III mostly included earlier generation devices. 
The recent thrombectomy trials have incorporated the stent-retriever technology, but their generalizability remains unknown. Methods: The North American Solitaire Acute Stroke (NASA) registry recruited patients treated with the Solitaire FR ${ }^{T M}$ device between March 2012 and February 2013. The NASA-IMS-III-Like Group (NILG baseline NIHSS score $\geq 10$ who received IV rt-PA) was compared to the IV rt-PA and IV + intra-arterial (IA)-IMS-III groups and the MR CLEAN, ESCAPE, SWIFT Prime, and REVASCAT trial controls to assess the stent-retriever treatment in the 'realworld' setting. The NILG was also compared to non-IV rt-PA NASA patients to evaluate the impact of IV rt-PA on thrombectomy. Results: A total of 136 of the 354 NASA patients fulfilled criteria for the NILG. Baseline characteristics were well balanced across groups. Time from onset to puncture was higher in NILG than IV+IA-IMS-III patients ( $274 \pm 112$ vs. $208 \pm 47$ min, $p<$ 0.0001). Occlusions involving the intracranial ICA, MCA-M1, or basilar arteries were more common in NILG than IV+IA-IMS-III patients (91.2 vs. 47.2\%, $p<0.00001)$. Modified thrombolysis in cerebral infarction $\geq 2 \mathrm{~b}$ reperfusion was higher in NILG than IV+IA-IMS-III patients (74.3 vs. $39.6 \%, p<0.00001)$. A 90-day modified Rankin Scale score $\leq 2$ was more frequent in the NILG than IV+IA-IMS-III patients (51.9 vs. $40.8 \%, \mathrm{p}=0.03$ ) and MR CLEAN (51.9 vs. $19.1 \%, \mathrm{p}<0.00001)$, ESCAPE (51.9 vs. $29.3 \%, p=0.0002)$, SWIFT Prime (51.9 vs. $35.5 \%, p=0.02)$, and REVASCAT (51.9 vs. $28.2 \%, p=0.0003$ ) controls. Symptomatic intracranial hemorrhage definitions varied across the different studies with rates ranging from $2.7 \%$ (ESCAPE) to $11.9 \%$ (NILG). The NILG 90-day mortality (24.4\%) was higher than in SWIFT Prime but comparable to all other groups. IV rt-PA was an independent predictor of good outcome in NASA (OR $=2.3,95 \%$ CI 1.2-4.7). Conclusion: Our results support the 'real-world' applicability of the recent thrombectomy trials.

(C) 2016 S. Karger AG, Basel

\section{Introduction}

The Interventional Management of Stroke III (IMS-III) trial demonstrated no significant difference between treatments with intravenous recombinant tissue plasminogen activator (IV rt-PA) alone and IV rt-PA followed by endovascular therapy [1]. However, this trial utilized mostly earlier generations of devices and did not evaluate the efficacy of newer devices now known to have higher rates of reperfusion [2]. The subsequent thrombectomy trials including MR CLEAN, ESCAPE, EXTEND-IA, SWIFT Prime, and REVASCAT incorporated the newer stent retriever technology as the only or main endovascular reperfusion strategy and clearly demonstrated a strong benefit of mechanical thrombectomy over medical treatment alone [3-7]. However, these trials were highly selective about which patients and treatment centers they include, and the generalizability of their results in the 'real-world' setting remains unknown. Here, we present data on an 'IMS-III-Like Group' from the North American Solitaire Acute Stroke (NASA) registry, a repository database of the Solitaire FR $^{\mathrm{TM}}$ stent retriever. An exploratory analysis was performed to compare these results to the IMS-III IV rt-PA and combined IV/IA groups to investigate how the stent retriever technology would have influenced the IMS-III trials. We also analyzed how these patients compare to the control groups from the recent trials using the newer technology as an attempt to demonstrate the superiority of stent-retriever thrombectomy over medical treatment alone in a setting outside the clinical trial environment.

\section{Methods}

The NASA registry was an investigator-initiated registry that recruited 24 clinical sites within North America to submit retrospective demographic, clinical presentation, site-adjudicated angiographic, procedural, and clinical outcome data (90-day modified Rankin Scale, mRS, score) on consecutive patients treated 
with the Solitaire device from March 2012 to February 2013. The overall NASA results and detailed methodology have been published elsewhere [8-10]. Essentially, patients presenting within $8 \mathrm{~h}$ from symptom onset of an anterior circulation large vessel occlusion or within $12 \mathrm{~h}$ of a vertebrobasilar occlusion were included. The thrombolysis in myocardial infarction (TIMI) and modified thrombolysis in cerebral infarction (mTICI) reperfusion scales were defined according to the Solitaire With the Intention for Thrombectomy (SWIFT) and Trevo versus Merci Retrievers for Thrombectomy Revascularization of Large Vessel Occlusions in Acute Ischemic Stroke (TREVO 2) clinical trial definitions with successful reperfusion defined as mTICI/TIMI $\geq 2$ $[11,12]$. The time from stroke onset to reperfusion was defined as the time the patient was last seen well to successful reperfusion or the end of the procedure in cases for which reperfusion was not achieved. Symptomatic intracranial hemorrhage (sICH) was defined as any parenchymal hematoma, subarachnoid hemorrhage, or intraventricular hemorrhage associated with a worsening of the National Institutes of Health Stroke Scale (NIHSS) score of $\geq 4$ within $24 \mathrm{~h}$. Good functional outcome was defined as a 90-day mRS score $\leq 2$. Adjuvant therapy was defined as any additional drug (i.e. intra-arterial, IA, lytic) or mechanical device modality used other than the Solitaire FR stent retriever. Reperfusion, angiographic data, hemorrhage type, and clinical outcome were adjudicated by each individual center. There was no industry sponsorship or funding for the registry. Institutional review board approval was obtained from each institution's review board; only de-identified information was submitted to the coordinating center.

For the primary aim of the current study, we identified the cohort of NASA patients who would have met inclusion criteria for the IMS-III trial [i.e. received IV rt-PA and had a NIHSS score of $\geq 10$ on presentation NASA-IMS-III-Like Group (NILG)] and compared their baseline characteristics and outcomes to the results of the IV rt-PA and the combined IV rt-PA and IA treatment groups from the IMS-III trial as well as to the control groups from the MR CLEAN, ESCAPE, SWIFT Prime, and REVASCAT trials. Additionally, we compared the outcomes of the NILG to those NASA patients not receiving IV rt-PA as an attempt to establish whether IV rt-PA could have any beneficial or deleterious effect in patients treated with stent retriever.

\section{Statistical Analysis}

For the comparisons between NILG and the IMS-III, MR CLEAN, ESCAPE, SWIFT Prime, and REVASCAT trials, dichotomous outcomes were analyzed by using the number of events in each group and the total number of participants in order to calculate the risk ratio. For continuous variables, the means and standard deviations from each study were used to calculate the mean difference. A random-effects model was utilized. Analyses were performed with RevMan (Review Manager, version 5.3., Copenhagen, The Nordic Cochrane Centre, The Cochrane Collaboration, 2014).

For the NASA registry data, descriptive, univariate, and multivariate statistics were performed using the JMP 10 software (SAS Institute, Cary, N.C., USA). Baseline and outcomes variables of the NILG patients were compared to the non-IV rt-PA NASA patients using the Fisher exact test and $\chi^{2}$ test for categorical variables and the Student $t$ test and unpaired $t$ test for continuous variables. Additionally, we performed a univariate analysis of predictors of good outcomes in the NASA registry. Then, variables with a p value of $<0.10$ were entered into the multivariate binary logistic regression model to determine the independent predictors of good clinical outcomes. Statistical significance was set at $\mathrm{p}<0.05$.

\section{Results}

A total of 354 patients were enrolled in the NASA registry across the 24 participating centers with 136 patients fulfilling the inclusion criteria for NILG (i.e. treatment with IV rt-PA, baseline NIHSS score $\geq 10$, known 90 -day mRS score). Table 1 displays the comparison of the baseline characteristics between the NILG $(n=136)$ versus the combined IV+IA $(n=434)$ and IV rt-PA only $(n=222)$ IMS-III arms and the control groups of the MR CLEAN $(n=267)$, ESCAPE $(n=150)$, SWIFT Prime $(n=98)$, and REVASCAT $(n=103)$ trials. The baseline variables were in general well balanced in terms of age, gender, and comorbidities with the exception of higher rates of atrial fibrillation and diabetes in NILG than MR CLEAN and higher rates of hypertension in NILG than SWIFT Prime. The mean/median NIHSS score on presentation was nominally higher in the NILG as compared to the other groups. The mean time from stroke onset to groin puncture (TOG) was significantly higher in the NILG as compared to the 


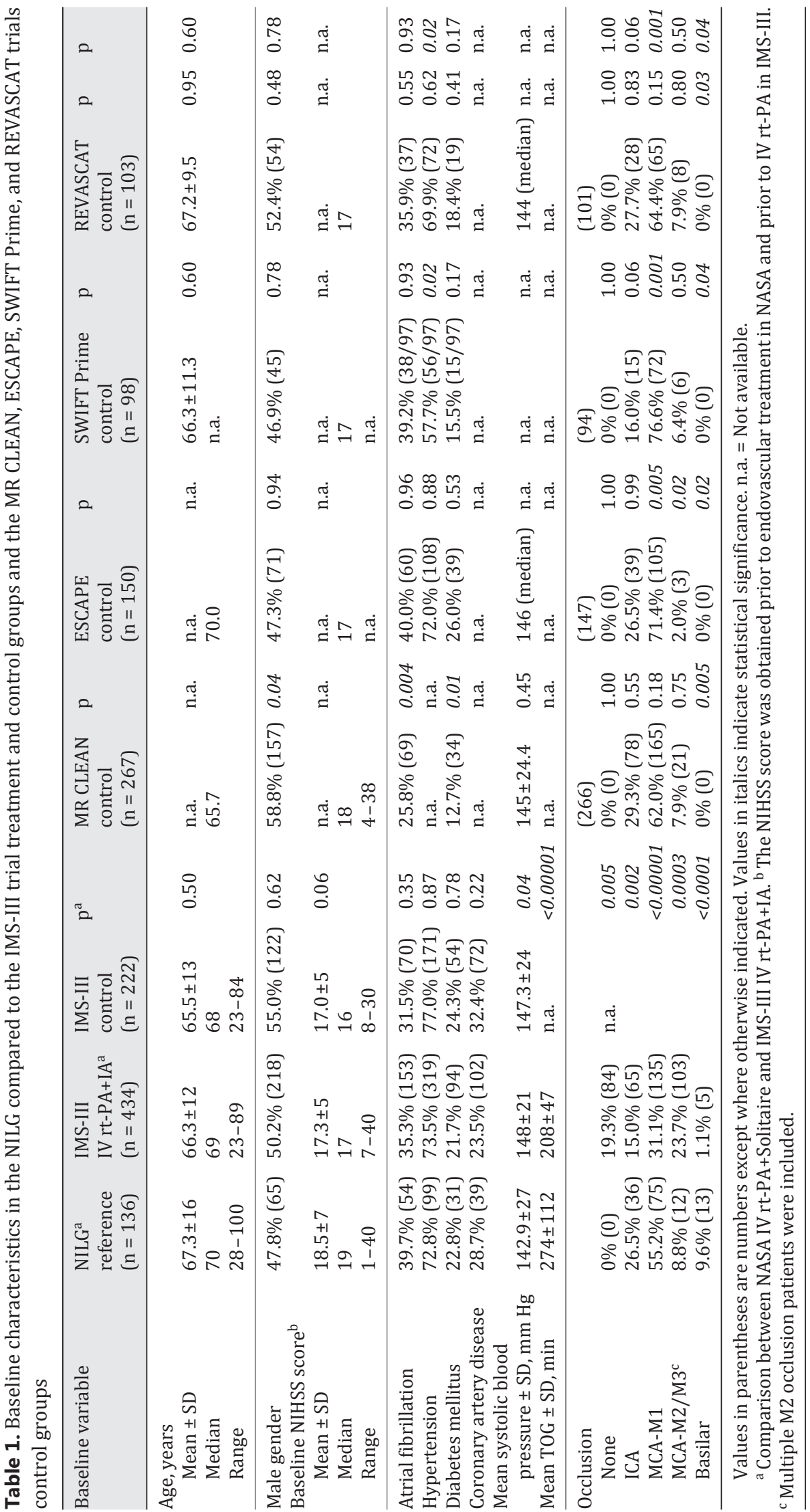




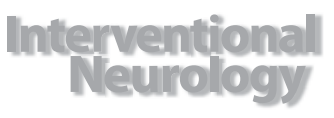

Table 2. Clinical and imaging outcomes in the NILG vs. the IMS-III trial treatment and control groups and the MR CLEAN, ESCAPE, SWIFT Prime, and REVASCAT trials control groups

\begin{tabular}{|c|c|c|c|c|c|c|c|c|c|c|c|c|}
\hline & $\begin{array}{l}\text { NILG }^{a} \\
\text { reference } \\
(\mathrm{n}=136)\end{array}$ & $\begin{array}{l}\text { IMS-III } \\
\text { IV rt-PA+IA } \\
(\mathrm{n}=434)\end{array}$ & $\begin{array}{l}\text { IMS-III } \\
\text { IV rt-PA } \\
\text { only } \\
(n=222)\end{array}$ & $\mathrm{p}^{\mathrm{a}}$ & $\begin{array}{l}\text { MR CLEAN } \\
\text { control } \\
(\mathrm{n}=267)\end{array}$ & $\mathrm{p}$ & $\begin{array}{l}\text { ESCAPE } \\
\text { control } \\
(n=150)\end{array}$ & $\mathrm{p}$ & $\begin{array}{l}\text { SWIFT } \\
\text { prime } \\
\text { control } \\
(\mathrm{n}=98)\end{array}$ & $\mathrm{p}$ & $\begin{array}{l}\text { REVASCAT } \\
\text { control } \\
(\mathrm{n}=103)\end{array}$ & $\mathrm{p}$ \\
\hline $\mathrm{mTICI} \geq 2 \mathrm{~b}$ & $74.3 \%(101)$ & $\begin{array}{l}39.6 \% \\
(126 / 318)\end{array}$ & n.a. & $<0.00001$ & n.a. & n.a. & n.a. & n.a. & n.a. & n.a. & n.a. & n.a. \\
\hline $\mathrm{sICH}^{\mathrm{b}}$ & $11.9 \%{ }^{\mathrm{b}}(9)$ & $6.2 \%^{\mathrm{b}}(27)$ & $5.9 \%(13)$ & 0.87 & $5.9 \%^{\mathrm{b}}(16)$ & 0.81 & $\begin{array}{l}2.7 \%^{\mathrm{b}} \\
(4 / 150)\end{array}$ & 0.12 & $\begin{array}{l}7.2 \%^{\mathrm{b}} \\
(7 / 97)\end{array}$ & 0.86 & $5.8 \%^{\mathrm{b}}(6)$ & 0.80 \\
\hline $\begin{array}{l}\text { 90-day mRS } \\
\text { score } \leq 2\end{array}$ & $51.9 \%(70)$ & $\begin{array}{l}40.8 \% \\
(169 / 415)\end{array}$ & $\begin{array}{l}38.7 \% \\
(83 / 215)\end{array}$ & 0.03 & $\begin{array}{l}19.1 \% \\
(51 / 267)\end{array}$ & $<0.00001$ & $\begin{array}{l}29.3 \% \\
(43 / 147)\end{array}$ & 0.0002 & $\begin{array}{l}35.5 \% \\
(33 / 93)\end{array}$ & 0.02 & $\begin{array}{l}28.2 \% \\
(29 / 103)\end{array}$ & 0.0003 \\
\hline $\begin{array}{l}\text { 90-day } \\
\text { mortality }\end{array}$ & $24.4 \%$ (33) & $19.1 \%(83)$ & $21.6 \%(48)$ & 0.19 & $22 \%(59)$ & 0.62 & $\begin{array}{l}19 \% \\
(28 / 147)\end{array}$ & 0.29 & $\begin{array}{l}12.4 \% \\
(12 / 97)\end{array}$ & 0.03 & $\begin{array}{l}15.5 \% \\
(16 / 103)\end{array}$ & 0.10 \\
\hline
\end{tabular}

Values in parentheses are numbers. Values in italics indicate statistical significance.

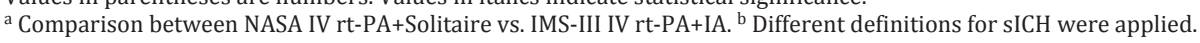

combined IV+IA-IMS-III group ( $274 \pm 112$ vs. $208 \pm 47$ min, p < 0.00001). Notably, there were significant differences in the presence and severity of intracranial occlusions amongst the NASA and IMS-III patients. Occlusions involving the intracranial ICA, MCA-M1, or basilar arteries were present in $91.2 \%$ of the NILG but only in $47.2 \%$ of the combined IV+IA-IMS-III group patients $(\mathrm{p}<0.00001)$. NILG had more basilar and relatively less MCA-M1 occlusions as compared to the newer thrombectomy trials (table 1).

Table 2 summarizes the clinical and imaging outcomes across the different study groups. There were significantly higher rates of optimal reperfusion (mTICI $\geq 2 \mathrm{~b}$ ) in the NILG than the combined IV+IA-IMS-III group patients (74.3 vs. $39.6 \%, p<0.00001)$. sICH definitions varied across the different studies with rates ranging from $2.7 \%$ (ESCAPE) to $11.9 \%$ (NILG). The rates of functional independence at 90 days ( $m R S$ score $\leq 2$ ) were significantly higher in the NILG compared to the combined IV+IA-IMS-III group (51.9 vs. $40.8 \%$, $\mathrm{p}=0.03$ ) and the IV rt-PA IMS-III group (51.9 vs. $38.7 \%, \mathrm{p}=0.02$ ) as well as to the MR CLEAN ( 51.9 vs. $19.1 \%, \mathrm{p}<0.00001$ ), ESCAPE (51.9 vs. $29.3 \%, \mathrm{p}=0.0002$ ), SWIFT Prime (51.9 vs. $35.5 \%, \mathrm{p}=0.02$ ), and REVASCAT (51.9 vs. $28.2 \%, \mathrm{p}=0.0003$ ) controls. The NILG 90 -day mortality was higher than in SWIFT Prime (24.4 vs. $12.4 \%, \mathrm{p}=0.03$ ) but comparable to all the other groups.

Logistic regression analysis including all NASA patients with available 90-day mRS outcome demonstrated that the use of IV rt-PA was an independent predictor of good outcomes at 90 days (OR $=2.3,95 \%$ CI $1.2-4.7, \mathrm{p}=0.02)$. Interestingly, this effect on clinical outcomes was not mediated by differences in recanalization rates as the prior usage of IV rt-PA did not influence the rates of reperfusion (tables 3-5).

\section{Discussion}

Our study supports the 'real-world' applicability of the recent thrombectomy trials, as in a large cohort of patients treated outside clinical trials, endovascular treatment with stent retrievers also seems to result in better outcomes as compared to medical treatment alone. We made this finding despite greater baseline stroke severity, longer time from stroke onset 
Table 3. NILG vs. NASA non-IV rt-PA baseline characteristics and outcomes

\begin{tabular}{|c|c|c|c|}
\hline Characteristic & $\begin{array}{l}\text { NASA } \\
\text { non IV rt-PA } \\
(n=179)\end{array}$ & $\begin{array}{l}\text { NASA } \\
\text { IV rt-PA+Solitaire } \\
(n=136)\end{array}$ & $\mathrm{p}$ \\
\hline Mean age $\pm S D$, years & $67.7 \pm 14$ & $67.3 \pm 16$ & 0.8 \\
\hline Males & $47.8 \%$ & $47.8 \%$ & 1.0 \\
\hline Mean baseline NIHSS score \pm SD & $17.8 \pm 6$ & $18.5 \pm 7$ & 0.3 \\
\hline Atrial fibrillation & $44.7 \%$ & $39.7 \%$ & 0.4 \\
\hline Hypertension & $79.3 \%$ & $72.8 \%$ & 0.2 \\
\hline Diabetes mellitus & $25.7 \%$ & $22.8 \%$ & 0.6 \\
\hline Coronary artery disease & $35.8 \%$ & $28.7 \%$ & 0.2 \\
\hline Mean systolic blood pressure $\pm \mathrm{SD}, \mathrm{mm} \mathrm{Hg}$ & $147 \pm 28$ & $142.9 \pm 27$ & 0.2 \\
\hline Mean TOG \pm SD, $\min$ & $436.7 \pm 289$ & $274 \pm 112$ & $<0.001$ \\
\hline \multicolumn{4}{|l|}{ Angiographic occlusion site } \\
\hline ICA & $22.4 \%(40)$ & $26.5 \%(36)$ & 0.2 \\
\hline MCA-M1 & $54.2 \%(97)$ & $55.2 \%(75)$ & 0.9 \\
\hline MCA-M2/M3 & $11.7 \%(21)$ & $8.8 \%(12)$ & 0.4 \\
\hline Basilar & $11.7 \%(21)$ & $9.6 \%(13)$ & 0.5 \\
\hline IA lytics & $27.4 \%$ & $30.9 \%$ & 0.5 \\
\hline Rescue therapy & $26.3 \%$ & $24.3 \%$ & 0.7 \\
\hline Balloon guide catheter & $37.1 \%$ & $48.5 \%$ & 0.06 \\
\hline General anesthesia & $69.6 \%$ & $68.4 \%$ & 0.9 \\
\hline $\mathrm{mTICI} \geq 2 \mathrm{~b}-3$ & $74.7 \%$ & $74.3 \%$ & 1.0 \\
\hline mTICI 3 & $41 \%$ & $41.2 \%$ & 1.0 \\
\hline sICH & $9.0 \%$ & $11.9 \%$ & 0.5 \\
\hline 90-day mRS score $\leq 2$ & $34.6 \%$ & $51.9 \%$ & 0.003 \\
\hline 90-day mortality & $34.1 \%$ & $24.4 \%$ & 0.08 \\
\hline
\end{tabular}

Values in parentheses are numbers. Values in italics indicate statistical significance.

to treatment, and more proximal location of arterial occlusions in the NASA patient cohort as compared to the IMS-III patients. A similar benefit was suggested by the comparison with the control groups of the MR CLEAN, ESCAPE, SWIFT Prime, and REVASCAT trials.

The IMS-III trial was limited by the use of earlier generation devices and does not reflect current practice. Patients undergoing mechanical thrombectomy in IMS-III were treated with what is now considered an obsolete technology (e.g. the Merci retriever, 28.4\% patients, and the first generation of the Penumbra thromboaspiration system, $16.2 \%$ patients). Only 5 of the 334 IMS-III patients (1.5\%) treated with endovascular therapy received stent-retriever treatment. More remarkably, almost half of the endovascular allocated IMS-III patients were treated with IA rt-PA alone [2]. In contrast, the MR CLEAN, ESCAPE, EXTEND-IA, SWIFT Prime, and REVASCAT trials utilized stent retrievers as the sole or main reperfusion treatment in the vast majority of their patients [3-7]. By achieving faster and better (both quantitatively and qualitatively) reperfusion, these trials demonstrated a remarkable benefit of thrombectomy over medical treatment alone.

A potential criticism to the aforementioned trials is the one of over-selection - raising questions about how generalizable their results are in a larger and less controlled setting. While, due to their uncontrolled nature, registries have a clear disadvantage in definitely proving an intervention, they have an advantage when it comes to the evaluation of how applicable a new therapy is in a broader and more liberal environment. The NASA registry encompassed over 20 different centers with a wider variation in practice patterns, imaging selection paradigms, and treatment algorithms than what is observed in any of the recent 
Table 4. NASA univariate analysis of predictors of 90-day functional outcomes

\begin{tabular}{|c|c|c|c|}
\hline & $\begin{array}{l}\text { mRS score } \leq 2 \\
(n=132)\end{array}$ & $\begin{array}{l}\text { mRS score }>2 \\
(n=183)\end{array}$ & $\mathrm{p}$ \\
\hline \multicolumn{4}{|l|}{ Demographics } \\
\hline Mean age \pm SD, years & $65.0 \pm 15.1$ & $69.2 \pm 14.4$ & 0.02 \\
\hline Females & $69(52.7)$ & $95(51.9)$ & 0.89 \\
\hline Mean baseline NIHSS (range) & $15(12-20)$ & $19(16-24)$ & $<0.0001$ \\
\hline White ethnicity & $101(77.7)$ & $132(72.5)$ & 0.54 \\
\hline \multicolumn{4}{|l|}{ Comorbidities } \\
\hline Hypertension & $95(72.0)$ & $146(79.8)$ & 0.11 \\
\hline Atrial fibrillation & $52(39.4)$ & $83(45.4)$ & 0.29 \\
\hline Diabetes mellitus & $27(20.5)$ & $50(27.3)$ & 0.16 \\
\hline Hyperlipidemia & $63(47.7)$ & $101(55.2)$ & 0.19 \\
\hline Smoking history & $42(32.1)$ & 53 (29.3) & 0.60 \\
\hline Coronary artery disease & $40(30.3)$ & $63(34.4)$ & 0.44 \\
\hline \multicolumn{4}{|l|}{ Clinical presentation } \\
\hline Occlusion site & & & 0.06 \\
\hline MCA-M1 & $81.0(61.4)$ & $90.0(49.5)$ & \\
\hline ICA & $23.0(17.4)$ & $53(29.1)$ & \\
\hline Vertebrobasilar & $12(9.1)$ & $22(12.1)$ & \\
\hline Mean initial systolic blood pressure \pm SD, mm Hg & $140.3 \pm 25.5$ & $148.6 \pm 28.6$ & 0.01 \\
\hline Mean initial diastolic blood pressure $\pm \mathrm{SD}, \mathrm{mm} \mathrm{Hg}$ & $76.7 \pm 15.6$ & $79.9 \pm 18.8$ & 0.10 \\
\hline IV rt-PA & $70(53.0)$ & $65(35.7)$ & 0.002 \\
\hline \multicolumn{4}{|l|}{ Procedural factors } \\
\hline Mean $\mathrm{TOG} \pm \mathrm{SD}, \min$ & $338.7 \pm 229.1$ & $384.6 \pm 251.6$ & 0.10 \\
\hline Mean time to revascularization or end of & $594+705$ & $799+798$ & 003 \\
\hline General anesthesia & $\begin{array}{l}59.4 \pm 70.5 \\
62.0(60.2)\end{array}$ & $113(75.8)$ & $\begin{array}{l}0.03 \\
0.008\end{array}$ \\
\hline IA rt-PA & $34.0(25.8)$ & $56.0(30.6)$ & 0.35 \\
\hline Use of balloon guide catheter & $65.0(51.2)$ & $61.0(35.5)$ & 0.007 \\
\hline Mean number of passes \pm SD & $1.5(0.84)$ & $2.0(1.1)$ & $<0.0001$ \\
\hline Use of rescue therapy & $16.0(12.1)$ & $65.0(35.5)$ & $<0.0001$ \\
\hline \multicolumn{4}{|l|}{ Imaging outcomes } \\
\hline $\mathrm{mTICI} \geq 2 \mathrm{a}$ & $127(96.2)$ & $153.0(83.6)$ & 0.0004 \\
\hline $\mathrm{mTICI} \geq 2 \mathrm{~b}$ & $118.0(89.4)$ & $115.0(63.2)$ & $<0.0001$ \\
\hline sICH & $3.0(2.3)$ & $29.0(16.0)$ & $<0.0001$ \\
\hline
\end{tabular}

Table 5. NASA multivariate analysis of predictors of good 90-day functional outcomes

\begin{tabular}{lcl}
\hline & Good outcome, OR $(95 \% \mathrm{CI})$ & $\mathrm{p}$ \\
\hline mTICI $\geq 2 \mathrm{~b}$ & $5.8(2.2-12.6)$ & 0.0002 \\
Baseline NIHSS score & $0.91(0.89-0.96)$ & 0.001 \\
sICH & $0.1(0.02-0.4)$ & 0.01 \\
General anesthesia & $0.4(0.2-0.8)$ & 0.01 \\
Rescue therapy & $0.4(0.2-0.8)$ & 0.01 \\
Use of IV rt-PA & $2.3(1.2-4.7)$ & 0.02 \\
Balloon guide catheter & $2.2(1.1-4.3)$ & 0.03 \\
Age & $0.98(0.96-1.0)$ & 0.11 \\
TOG & $0.99(0.99-1.0)$ & 0.45 \\
\hline
\end{tabular}

Values in italics indicate statistical significance. 
thrombectomy trials. Despite that, similar rates of recanalization and good outcomes were seen, supporting the notion that as long as the procedure is done by experienced operators and centers, the benefit of early thrombectomy seem to be generalizable. Our results are further supported by a recent study from the REVASCAT investigators demonstrating that their trial patients treated with endovascular therapy had similar outcomes to patients treated in a parallel population-based endovascular stroke reperfusion registry [13].

Another important finding in our analysis is that the use of IV rt-PA was found to be an independent predictor of good outcome in the NASA registry. Notably, we could not find an association between TOG and outcomes. Therefore, IV rt-PA does not seem to be a confounder for time to treatment. However, there might have been unaccounted differences between patients who received IV rt-PA and those who did not. Notably, we could not adjust for differences in baseline ASPECTS across the two groups since ASPECTS was not collected in the NASA registry. Interestingly, there was no difference in the rates of $\mathrm{mTICI} \geq 2 \mathrm{~b}$ or TICI 3 reperfusion between NASA patients treated with IV rt-PA and those not treated with IV rt-PA. Thus, any potential benefit of IV rt-PA in this setting appears to be unrelated to its reperfusion mechanism. This finding is consistent with a recent study demonstrating lower rates of infarct growth in fully reperfused patients who received IV rt-PA prior to thrombectomy than in those who did not and supports the recent experimental data suggesting a neuroprotective effect to rt-PA $[14,15]$. Our study also adds to the increasing body of evidence demonstrating the safety of rescue end ovascular therapy following intraven ous thrombolysis, as no difference in the rates of sICH were seen amongst NASA patients who did and those who did not receive IV rt-PA (11.9 vs. 9.0\%, p = 0.5) [1, 3-6, 16]. Given the safety of thrombectomy before IV rt-PA and its potential benefit in the clinical outcomes, our results favor the combined IV+IA approach rather than the IV or IA approaches in isolation. However, a prospective clinical trial is needed to confirm these findings.

There are important limitations to our study with many of them being related to its retrospective nature. The comparison with the IMS-III, MR CLEAN, ESCAPE, SWIFT Prime, and REVASCAT trials was not performed at a patient level. However, baseline NIHSS score, age, comorbidities, and vascular occlusion sites were either similar across groups or adversely affected the NILG. The NILG had a slightly lower baseline systolic blood pressure than IMS-III patients. Lower systolic blood pressure has been linked to higher recanalization rates, so it is possible that this small imbalance may have favored the NILG outcomes [17]. Moreover, NASA did not collect baseline ASPECTS which is one of the strongest determinants of outcomes after endovascular therapy [18]. However, it is unlikely that IMS-III patients had higher stroke burden on presentation than NILG patients given the higher baseline NIHSS score, longer TOG, and higher frequency of ICA, MCA-M1, and basilar occlusions observed in NILG than IMS-III patients. Similarly, the control groups of the MR CLEAN, ESCAPE, SWIFT Prime, and REVASCAT trials had high median ASPECTS $(9,9,9$, and 8, respectively), so it is unlikely that the NILG would have significantly better ASPECTS mostly when considering the nominal differences in the median baseline NIHSS score across the different groups. Mortality in the NILG was comparable to most studies but was higher than in SWIFT Prime, potentially due to a higher stroke severity and the inclusion of basilar occlusions in the NILG. Finally, adjudication of reperfusion and clinical outcomes was performed locally at each site, without a core laboratory or requirement of an independent adjudicator. This lack of central adjudication may be biased toward better outcomes in NASA than in the randomized trials. Ongoing prospective registries involving the Solitaire and Trevo devices should overcome these limitations and provide a more definite proof of the generalizability of stent-retriever thrombectomy. 


\section{Conclusion}

In agreement with the recent trials, stent-retriever bridging therapy for large vessel occlusion strokes seems to result in better outcomes than intravenous thrombolysis alone even when performed outside the more rigid and selective clinical trial environment.

\section{Disclosure Statement}

Dr. Nogueira, Dr. Zaidat, and Dr. Gupta are consultant/advisory board members of Covidien and Stryker Neurovascular. Dr. Malisch is a member of the DSMB SWIFT Trial. Dr. Linfante is a consultant for Covidien. Dr. Rai is a consultant/advisory board member of Stryker Neurovascular. Dr. English is a consultant for Stryker Neurovascular. Dr. Abraham is a consultant of Stryker Neurovascular and a member of the speaker's bureau for Boehringer Ingelheim. The other authors have no conflicts of interest to disclose.

\section{References}

1 Broderick JP, Palesch YY, Demchuk AM, Yeatts SD, Khatri P, Hill MD, Jauch EC, Jovin TG, Yan B, Silver FL, von Kummer R, Molina CA, Demaerschalk BM, Budzik R, Clark WM, Zaidat O0, Malisch TW, Goyal M, Schonewille WJ, Mazighi M, Engelter ST, Anderson C, Spilker J, Carrozzella J, Ryckborst KJ, Janis LS, Martin RH, Foster LD, Tomsick TA: Endovascular therapy after intravenous t-PA versus t-PA alone for stroke. N Engl J Med 2013; 368:893-903.

2 Nogueira RG, Gupta R, Davalos A: IMS-III and synthesis expansion trials of endovascular therapy in acute ischemic stroke: how can we improve? Stroke 2013;44:3272-3274.

3 Berkhemer OA, Fransen PS, Beumer D, van den Berg LA, Lingsma HF, Yoo AJ, Schonewille WJ, Vos JA, Nederkoorn PJ, Wermer MJ, van Walderveen MA, Staals J, Hofmeijer J, van Oostayen JA, Lycklama a Nijeholt GJ, Boiten J, Brouwer PA, Emmer BJ, de Bruijn SF, van Dijk LC, Kappelle LJ, Lo RH, van Dijk EJ, de Vries J, de Kort PL, van Rooij WJ, van den Berg JS, van Hasselt BA, Aerden LA, Dallinga RJ, Visser MC, Bot JC, Vroomen PC, Eshghi O, Schreuder TH, Heijboer RJ, Keizer K, Tielbeek AV, den Hertog HM, Gerrits DG, van den Berg-Vos RM, Karas GB, Steyerberg EW, Flach HZ, Marquering HA, Sprengers ME, Jenniskens SF, Beenen LF, van den Berg R, Koudstaal PJ, van Zwam WH, Roos YB, van der Lugt A, van Oostenbrugge RJ, Majoie CB, Dippel DW; MR Clean Investigators: A randomized trial of intraarterial treatment for acute ischemic stroke. N Engl J Med 2015;372: $11-20$.

4 Goyal M, Demchuk AM, Menon BK, Eesa M, Rempel JL, Thornton J, Roy D, Jovin TG, Willinsky RA, Sapkota BL, Dowlatshahi D, Frei DF, Kamal NR, Montanera WJ, Poppe AY, Ryckborst KJ, Silver FL, Shuaib A, Tampieri D, Williams D, Bang OY, Baxter BW, Burns PA, Choe H, Heo JH, Holmstedt CA, Jankowitz B, Kelly M, Linares G, Mandzia JL, Shankar J, Sohn SI, Swartz RH, Barber PA, Coutts SB, Smith EE, Morrish WF, Weill A, Subramaniam S, Mitha AP, Wong JH, Lowerison MW, Sajobi TT, Hill MD; ESCAPE Trial Investigators: Randomized assessment of rapid endovascular treatment of ischemic stroke. N Engl J Med 2015;372:1019-1030.

5 Campbell BC, Mitchell PJ, Kleinig TJ, Dewey HM, Churilov L, Yassi N, Yan B, Dowling RJ, Parsons MW, Oxley TJ, Wu TY, Brooks M, Simpson MA, Miteff F, Levi CR, Krause M, Harrington TJ, Faulder KC, Steinfort BS, Priglinger M, Ang T, Scroop R, Barber PA, McGuinness B, Wijeratne T, Phan TG, Chong W, Chandra RV, Bladin CF, Badve M, Rice H, de Villiers L, Ma H, Desmond PM, Donnan GA, Davis SM; EXTEND-IA Investigators: Endovascular therapy for ischemic stroke with perfusion-imaging selection. N Engl J Med 2015;372:1009-1018.

6 Saver JL, Goyal M, Bonafé A, Diener H, Levy E, Pereira VM, Albers G, Cognard C, Cohen DJ, Hacke W, Jansen O, Jovin TG, Mattle HP, Nogueira RG, Siddiqui AH, Yavagal DR, Devlin TG, Lopes DK, Reddy VK, du Mesnil de Rochemont R, Singer OC, Jahan R; SWIFT PRIME Investigators: Stent-retriever thrombectomy after intravenous t-PA vs. t-PA alone in stroke. N Engl J Med 2015;372:2285-2295.

7 Jovin TG, Chamorro A, Cobo E, de Miquel MA, Molina CA, Rovira A, San Roman L, Serena J, Abilleira S, Ribo M, Millan M, Urra X, Cardona P, Lopez-Cancio E, Tomasello A, Castano C, Blasco J, Aja L, Dorado L, Quesada H, Rubiera M, Hernandez-Perez M, Goyal M, Demchuk AM, von Kummer R, Gallofre M, Davalos A; REVASCAT Trial Investigators: Thrombectomy within $8 \mathrm{~h}$ after symptom onset in ischemic stroke. $\mathrm{N}$ Engl J Med 2015;372: 2296-2306.

8 Zaidat OO, Castonguay AC, Gupta R, Sun CH, Martin C, Holloway WE, Mueller-Kronast N, English JD, Linfante I, Dabus G, Malisch TW, Marden FA, Bozorgchami H, Xavier A, Rai AT, Froehler MT, Badruddin A, Nguyen TN, Taqi MA, Abraham MG, Janardhan V, Shaltoni H, Novakovic R, Yoo AJ, Abou-Chebl A, Chen PR, Britz GW, Kaushal R, Nanda A, Issa MA, Nogueira RG: North American Solitaire Stent Retriever Acute Stroke registry: post-marketing revascularization and clinical outcome results. J Neurointerv Surg 2014;6:584-588. 
9 Nguyen TN, Malisch T, Castonguay AC, Gupta R, Sun CH, Martin CO, Holloway WE, Mueller-Kronast N, English JD, Linfante I, Dabus G, Marden FA, Bozorgchami H, Xavier A, Rai AT, Froehler MT, Badruddin A, Taqi M, Abraham MG, Janardhan V, Shaltoni H, Novakovic R, Yoo AJ, Abou-Chebl A, Chen PR, Britz GW, Kaushal R, Nanda A, Issa MA, Masoud H, Nogueira RG, Norbash AM, Zaidat OO: Balloon guide catheter improves revascularization and clinical outcomes with the solitaire device: analysis of the North American Solitaire Acute Stroke Registry. Stroke 2014;45:141-145.

10 Abou-Chebl A, Zaidat O0, Castonguay AC, Gupta R, Sun CH, Martin CO, Holloway WE, Mueller-Kronast N, English JD, Linfante I, Dabus G, Malisch TW, Marden FA, Bozorgchami H, Xavier A, Rai AT, Froehler MT, Badruddin A, Nguyen TN, Taqi M, Abraham MG, Janardhan V, Shaltoni H, Novakovic R, Yoo AJ, Chen PR, Britz GW, Kaushal R, Nanda A, Issa MA, Nogueira RG: North American SOLITAIRE Stent-Retriever Acute Stroke Registry: choice of anesthesia and outcomes. Stroke 2014;45:1396-1401.

11 Saver JL, Jahan R, Levy EI, Jovin TG, Baxter B, Nogueira RG, Clark W, Budzik R, Zaidat O0; SWIFT Trialists: Solitaire flow restoration device versus the Merci Retriever in patients with acute ischaemic stroke (SWIFT): a randomised, parallel-group, non-inferiority trial. Lancet 2012;380:1241-1249.

12 Nogueira RG, Lutsep HL, Gupta R, Jovin TG, Albers GW, Walker GA, Liebeskind DS, Smith WS; TREVO 2 Trialists: Trevo versus Merci retrievers for thrombectomy revascularisation of large vessel occlusions in acute ischaemic stroke (TREVO 2): a randomised trial. Lancet 2012;380:1231-1240.

13 Urra X, Abilleira S, Dorado L, Ribo M, Cardona P, Millan M, Chamorro A, Molina C, Cobo E, Davalos A, Jovin TG, Gallofre M, Catalan Stroke Code and Reperfusion Consortium: Mechanical thrombectomy in and outside the REVASCAT trial: insights from a concurrent population-based stroke registry. Stroke 2015;46:3437-3442.

14 Haussen DC, Nogueira RG, Elhammady MS, Yavagal DR, Aziz-Sultan MA, Johnson JN, Gaynor BG, Jen S, Dehkharghani S, Peterson EC: Infarct growth despite full reperfusion in endovascular therapy for acute ischemic stroke. J Neurointerv Surg 2016;8:117-121.

15 Haile WB, Wu J, Echeverry R, Wu F, An J, Yepes M: Tissue-type plasminogen activator has a neuroprotective effect in the ischemic brain mediated by neuronal TNF-alpha. J Cereb Blood Flow Metab 2012;32:57-69.

16 Nogueira RG, Yoo AJ, Masrur S, Batista LM, Hakimelahi R, Hirsch JA, Schwamm LH: Safety of full-dose intravenous recombinant tissue plasminogen activator followed by multimodal endovascular therapy for acute ischemic stroke. J Neurointerv Surg 2013;5:298-301.

17 Nogueira RG, Liebeskind DS, Sung G, Duckwiler G, Smith WS: Predictors of good clinical outcomes, mortality, and successful revascularization in patients with acute ischemic stroke undergoing thrombectomy: pooled analysis of the Mechanical Embolus Removal in Cerebral Ischemia (MERCI) and Multi MERCI Trials. Stroke 2009;40:3777-3783.

18 Hill MD, Rowley HA, Adler F, Eliasziw M, Furlan A, Higashida RT, Wechsler LR, Roberts HC, Dillon WP, Fischbein NJ, Firszt CM, Schulz GA, Buchan AM: Selection of acute ischemic stroke patients for intra-arterial thrombolysis with pro-urokinase by using aspects. Stroke 2003;34:1925-1931. 